\title{
PENGARUH PENAMBAHAN UBI JALAR UNGU (IPOMEA BATATAS L.) TERHADAP SIFAT ORGANOLEPTIK DAN AKTIVITAS ANTIOKSIDAN PADA KUE YANGKO
}

\author{
Ir. Made Suladra, MP
}

\begin{abstract}
Yangko is a kind of traditional food from Yogyakarta and purple sweet potato is a source of anthocyanin which functions as an antioxidant. This study is entitled "The effect of adding purple sweet potato (ipomeabatatas 1.) To organoleptic properties and antioxidant activity in yam cake" which aims to find out: (1) concentration of purple sweet potato flour (Ipomoea batatas L) which is still preferred (2) fiber content food and antioxidant activity; (3) the shelf life of the selected purple sweet potato Yangko (Ipomoea batatas L) cake.The design of this study used a randomized complete design with 4 (four) treatments, namely purple sweet potato flour substitution at successive concentrations: $0 \% ; 15 \% ; 30 \%$; and 50\%. Each treatment was analyzed organoleptic and chemical properties using analysis of variance (anava), and if there were differences between treatments, it was continued with Duncan's Multiple Range Test at a significance level of 5\%.The results showed that the addition of various concentrations of purple sweet potato flour to Yangko cakes could significantly increase; water content, food fiber content and antioxidant activity. Substitution or addition at a concentration of $30 \%$ purple sweet potato flour can produce Yangko cakes which are still preferred and have; dark purple, purple sweet potato taste, soft texture, $43.21 \%$ water content, $17.38 \%(\mathrm{db})$ dietary fiber content, antioxidant activity $93.53 \%(\mathrm{db})$, and shelf life for 4 days at room temperature.
\end{abstract}

Keywords: glutinous rice flour, purple sweet potato flour, antioxidants, and food fiber.

\begin{abstract}
ABSTRAK
Kue Yangko merupakan salah satu jenis makanan tradisional khas Yogyakarta dan ubi jalar ungumerupakan sumber antosianin yang berfungsi sebagai antioksidan. Penelitian ini berjudul" Pengaruh penambahan ubi jalar ungu (ipomea batatas l.) terhadap sifat organoleptik dan aktivitas antioksidan pada kue yangko" yang bertujuanmengetahui: (1)konsentrasitepung ubi ungu (Ipomoea batatas L) yang yang masih disukai (2) kandunganseratpangandanaktivitas antioksidan; (3) umur simpan kue Yangko ubi jalarungu (Ipomoea batatas $L$ ) yang terpilih. Rancangan penelitian ini menggunakan rancangan acak lengkap dengan 4 (empat) perlakuan yaitu substitusitepung ubi jalarungupadakonsentrasi berturut-turut:0\%;15\%; $30 \%$; dan50\%. Masing-masing perlakuan dianalisis sifat organoleptik dan sifat kimia menggunakan analisis of varian (anava), dan apabila ada perbedaan diantara perlakuan, dilanjutkan dengan uji Duncan's Multiple Range Test pada taraf signifikansi $\quad 5 \quad \%$ Hasilpenelitianmenunjukkanbahwapenambahanpada berbagaikonsentrasitepungubijalarungupada kue Yangko dapatmeningkatkan secarasignifikan; kadarair, kadar serat pangan dan aktivitas antioksidan. Substitusi atau penambahanpadakonsentrasi30 \% tepung ubi jalar ungu dapat menghasilkan kue Yangko yang masih disukaidanmemiliki;warna ungu tua, rasa ubi jalar ungu, tekstur empuk, kadar air 43,21\%, kadar serat pangan 17,38 \% (db),aktivitas antioksidan 93,53\% (db), dan umur simpanselama 4 haripadasuhuruang.
\end{abstract}

Kata kunci : tepung ketan, tepung ubi jalar ungu, antioksidan, danserat pangan.

\section{A. PENDAhuluan}

Makanan tradisional merupakan salah satu aset budaya yang penting untuk dilestarikan dan dikembangkan. Makanan tradisional merupakan makanan yang sudah lama dikenal dan resep yang digunakan untuk membuat makanan tradisional dibuat oleh nenek moyang kemudian diajarkan secara turun temurun. Kue Yangko adalah makanan khas Yogyakarta atau tepatnya Kotagede yang terbuat dari adonan tepung ketan yang dibalut tepung gula dengan rasa manis yang khas karena ada unsur rasa gurih. Makanan Yangko merupakan salah satu bentuk keanekaragamaan makanan tradisional Daerah Istimewa Yogyakarta yang perlu dilestarikan dan ditingkatkan keanekaragamannya menjadi makanan yang tidak hanya sebagai sumber 
karbohidrat yang berasal dari beras ketan dan gula pasir, tetapi juga memiliki kandungan serat pangan dan antioksidan yang tinggi sehingga dapat manfaat bagi kesehatan.

Menurut Husnah (2010) tepung ubi jalar ungu varietas Ayamurasaki memiliki kandungan senyawa antosianin yang tinggi yaitu 188,11 mg Cy-3-glikosida /100 gram tepung dan serat kasar 3,60\% (db). Oleh karena itu pemanfaatan ubi jalar ungu memiliki peran yang penting sebagai antioksidan dan serat pangan dalam makanan olahan untuk kesehatan tubuh, karena antosianin memiliki kemampuan sebagai antimutagenik dan antikarsinogenik (Singh, S., dkk., 2008).

Berbagai penelitian membuktikan bahwa beberapa flavonoids yang terdapat dalam ubi jalar ungu memiliki khasiat antioksidan, karena mikronutrien yang merupakan gugus fitokimia dari berbagai bahan makanan yang berasal dari tumbuh-tumbuhan tersebut diyakini sebagai proteksi terhadap oksidatif. Salah satu jenis flavonoid dari tumbuhtumbuhan yang dapat berfungsi sebagai antioksidan adalah zat warna alami yang disebut antosianin ( Winarno, 2004).

Ubi jalar memiliki mutu yang baik ditinjau dari kandungan gizinya, terutama sebagai sumber karbohidrat, mineral, serat dan vitamin (Direktorat Kacang-kacangan dan Umbi-umbian (2002) dalam Ginting dkk.,2011). Ubi jalar kaya akan kandungan serat, karbohidrat kompleks, dan rendah kalori. Hal ini sangat menguntungkan bagi penderita diabetes karena bisa mengontrol atau memperlambat peningkatan kadar gula dalam darah penderita (Jawi, dkk., 2007).

Keberadaan senyawa antosianin sebagai sumber antioksidan alami di dalam ubi jalar ungu cukup menarik untuk dikaji, seiring dengan meningkatnya kesadaran masyarakat akan pentingnya hidup sehat. Bahan pangan yang kini mulai banyak diminati konsumen bukan saja yang mempunyai penampakan dan citarasa yang menarik, tetapi juga harus memiliki fungsi fisiologis tertentu bagi tubuh. Senyawa antosianin pada ubi jalar ungu menjadikan jenis bahan pangan sangat menarik untuk diolah menjadi makanan yang mempunyai nilai fungsional. Oleh karena itu untuk mengangkat dan melestarikan makanan tradisional Yangko ini, perlu dilakukan penelitian tentang pengolahan kue Yangko dengan substitusi tepung ketan putih dengan tepung ubi jalar ungu (Ipomea batatas L.) dengan tujuan untuk mendapatkan komposisi tepung ubi jalar ungu pada kue Yangko yang memiliki sifat organoleptik disukai dan mengandung antioksidan yang tinggi.

\section{B. METODE}

\section{Bahan dan Alat}

Bahan yang digunakan dalam penelitian ini yaitu ubi jalar ungu (Ipomoea batatas), gula pasir, dan beras ketan putih. Bahan kimia yang digunakan dalam pengujian yaitu aquadest, ethanol $95 \%, \mathrm{HCl}$, Butyilated Hydroxy Toluen), larutan DPPH. Alat yangdigunakan dalam pengujian yaitu panci, kompor, alat gelas ukur, alat gelas volume, gelas ukur, spektrofotometer, timbangan analitik, botol timbang, dan alat uji organoleptik.

\section{Cara Penelitian}

Tepung beras ketan dibuat dengan cara rendam beras ketan putih semalaman, tiriskan dan dijemur di bawah sinar matahari hingga kering kemudian ditepung halus menggunakan grinder. Tepung di ayak dengan ayakan 80 mesh, kemudian disangrai 10 menit.

Tepung ubi jalar ungu dibuat dengan cara ubi jalar ungu segar dicuci, dikupas kulitnya, dikecilkan ukurannya dengan cara disawut, dijemur dibawah sinar matahari selama 5 jam hingga kering. Ubi ungu yang telah kering digiling hingga menjadi tepung dan diayak menggunakan ayakan 80 mesh, kemudian disangrai selama 10 menit.

Campuran tepung ketan sangrai dan tepung ubi jalar ungu sangrai secara bertahap kedalam larutan gula dan diaduk hingga terbentuk adonan yang kental dan kompak. Komposisi perbandingan dibuat 4 perlakuan 
yang memiliki variasi konsentrasi tepung ubi jalar ungu seperti pada Tabel 1.

Tabel 1. Perbandingan Tepung Ketan dan Tepung Ubi Jalar Ungu Sangrai.

\begin{tabular}{|l|c|c|c|c|}
\hline \multirow{2}{*}{\multicolumn{1}{|c|}{ Bahan }} & \multicolumn{4}{|c|}{ Konsentrasi Tepung Ubi } \\
\cline { 2 - 5 } & $\mathbf{0 \%}$ & $\mathbf{1 5 \%}$ & $\begin{array}{c}\mathbf{3 0} \\
\text { \% }\end{array}$ & $\begin{array}{c}\mathbf{5 0} \\
\text { \% }\end{array}$ \\
\hline Tepung Ketan (gr) & 300 & 255 & 210 & 150 \\
\hline $\begin{array}{l}\text { Tpg Ubi } \\
\text { Jalar Ungu (gr) }\end{array}$ & 0 & 45 & 90 & 150 \\
\hline Gula Pasir (gr) & 75 & 75 & 75 & 75 \\
\hline Air (ml.) & 200 & 200 & 200 & 200 \\
\hline
\end{tabular}

Tuangkan adonan ke dalam loyang, setelah dingin belah adonan dan dipotongpotong bentuk kotak ukuran $2 \mathrm{~cm}$, gulingkan ke sisa tepung dan dibungkus, kemudian dianalisis : 1) sifat kimia meliputi; kadar air dan kadar serta pangan (Sudarmadji, dkk., 2010)dan aktivitas antioksidan dengan metode DPPH (Jiao dkk., 2012); dan 2)sifat organoleptik meliputi; warna, rasa, tekstus, dan kesukaan (Bambang Kardika, dkk., 1988).

Hasil uji organoleptik Kue Yangko yang masih disukai oleh panelis ditetapkan sebagai konsentrasi terpilih, selanjutnya dikemas dalam kantong plasik yang tertutup dan disimpan pada suhu ruang selama: 1 hari, 4 hari, dan 7 hari. Selama penyimpanan dilakukan pengamatan dan analisis sifat organoleptik (warna, rasa, tekstur, kesukaan) dan aktivitas antioksidan.

Rancangan percobaan yang digunakan dalam penelitian ini adalah rancangan acak lengkap dan untuk mengetahui adanya perbedaan diantara perlakuan dianjutkan dengan analisa Duncan's Multiple Range Test (DMRT) pada taraf signifikansi $5 \%$ (Harsojuwono, dkk., 2011).

\section{HASIL DAN PEMBAHASAN}

1. Uji Organoleptik Kue Yangko Pada Berbagai Konsentrasi Tepung Ubi Jalar Ungu Sangrai

Analisis data dilakukan melalui pengecekan isian formulir kuesioner, memasukkan data dan analisis menggunakan uji sidik ragam atau analysis of variance (anova) pada derajat signifikan $(\alpha)=0,05$, jikap hitung $\leq$ p 0,05 artinya ada pengaruh nyata uji organoleptik kue Yangko ubi jalar ungu sebagai pangan fungsional. Hasil uji organoleptik terhadap sifat warna, rasa, tekstur dan kesukaan seperti pada Tabel 2.

Tabel 2. Hasil Uji Organoleptik Kue Yangko Pada Berbagai Konsentrasi Tepung Ubi Jalar Ungu.

\begin{tabular}{|c|c|c|c|c|c|}
\hline & \multicolumn{4}{|c|}{$\begin{array}{l}\text { Penambahan Tepung } \\
\text { Ubi jalar Ungu }\end{array}$} & \multirow{2}{*}{$\begin{array}{c}\text { Keteranga } \\
\text { n } \\
\text { Skor Tiap } \\
\text { Jenis Uji }\end{array}$} \\
\hline & $\begin{array}{l}0 \\
\%\end{array}$ & $\begin{array}{l}15 \\
\%\end{array}$ & $\begin{array}{l}30 \\
\%\end{array}$ & $\begin{array}{l}50 \\
\%\end{array}$ & \\
\hline a.Warna & $\begin{array}{l}1,0 \\
0^{\mathrm{b}}\end{array}$ & $\begin{array}{l}2,9 \\
6^{a}\end{array}$ & $\begin{array}{c}3,4 \\
8^{\mathrm{a}}\end{array}$ & $\begin{array}{l}4,4 \\
0^{\mathrm{a}}\end{array}$ & $\begin{array}{l}1=\text { Putih }- \\
\text { krem } \\
2=\text { sedikit } \\
\text { ungu } \\
3=\text { Ungu } \\
\text { muda } \\
4=\text { Ungu } \\
\text { tua } \\
5=\text { Sangat } \\
\text { Ungu }\end{array}$ \\
\hline b.Rasa & $\begin{array}{l}1,1 \\
6^{\mathrm{c}}\end{array}$ & $\begin{array}{l}2,9 \\
2^{\mathrm{cd}}\end{array}$ & $\begin{array}{l}3,1 \\
6^{\text {cd }}\end{array}$ & $\begin{array}{l}4,2 \\
8^{\mathrm{e}}\end{array}$ & $\begin{array}{l}1=\text { Gurih } \\
\text { beras } \\
\text { ketan } \\
\text { dominan } \\
2=\text { Agak } \\
\text { gurih } \\
\text { beras } \\
\text { ketan } \\
3=\quad \text { Ubi } \\
\text { jalar ungu } \\
4=\quad \text { Ubi } \\
\text { ungu } \\
\text { dominan } \\
5=\quad \text { Langu } \\
\text { dan tidak } \\
\text { enak }\end{array}$ \\
\hline c.Tekstur & $\begin{array}{l}2,4 \\
4^{\mathrm{f}}\end{array}$ & $\begin{array}{l}2,4 \\
0^{f}\end{array}$ & $\begin{array}{l}2,0 \\
4^{\mathrm{f}}\end{array}$ & $\begin{array}{l}2,1 \\
2^{\mathrm{f}}\end{array}$ & $\begin{array}{l}1=\text { Sangat } \\
\text { empuk } \\
2=\text { Empuk } \\
3=\text { Agak } \\
\text { empuk } \\
4=\text { Keras } \\
5=\text { Sangat } \\
\text { Keras }\end{array}$ \\
\hline d.Kesukaan & $\begin{array}{l}1,7 \\
6^{\mathrm{g}}\end{array}$ & $\begin{array}{l}2,6 \\
4^{\mathrm{g}}\end{array}$ & $\begin{array}{l}2,7 \\
2^{g}\end{array}$ & $\begin{array}{l}3,9 \\
2^{h}\end{array}$ & $\begin{array}{l}1=\text { Sangat } \\
\text { suka } \\
2=\text { Suka } \\
3=\text { Agak } \\
\text { suka } \\
4=\text { Tidak } \\
\text { suka } \\
5=\text { Sangat } \\
\text { tidak suka }\end{array}$ \\
\hline
\end{tabular}




\section{a. Warna}

Warna merupakan indikator pertama kita mengenai apakah suatu makanan diterima. Kita mengkaitkan warna-warna tertentu dengan makanan tertentu dan cenderung menolak makanan yang tidak dipenuhi. Warna menjadi atribut kualitas yang paling penting, walaupun suatu produk bernilai gizi tinggi, rasa enak dan tekstur baik namun jika warnanya kurang menarik, maka akan menyebabkan produk tersebut kurang diminati. Warna merupakan parameter pertama yang menentukan tingkat penerimaan konsumen terhadap suatu produk (Bambang Kartika, dkk., 1988).

Tabel 2 menunjukkan bahwa rata-rata kesukaan terhadap warna dalam pembuatan kue Yangko pada perlakuan konsentrasi $30 \%$ tepung ubi jalar ungu (nilai $3,48^{\mathrm{a}}$ ) ungu tua dan konsentrasi $50 \%$ tepung ubi jalar ungu (nilai $4,40^{\mathrm{a}}$ ) sangat ungu berbeda dengan perlakuan konsentrasi $0 \%$ tepung ubi jalar ungu berwarna putih krem (nilai $1,00^{\mathrm{b}}$ ) dan konsentrasi $15 \%$ tepung ubi jalar ungu berwarna sedikit ungu (nilai 2,96 ). Perlakuan konsentrasi $30 \%$ tepung ubi jalar ungu berwarna ungu tua (nilai3,48 ${ }^{\mathrm{a}}$ ) tidak berbeda nyata dengan konsentrasi $50 \%$ tepung ubi jalar ungu berwarnasangat ungu (nilai $4,40^{\mathrm{a}}$ ). Warna ungu ini disebabkan karena pigmen antosianin dalam ubi jalar ungu, sehingga kandungan antosianin yang tinggi pada ubi jalar ungu dapat berfungsi sebagai alternatif pewarna ungu alami.

Warna putih krem pada perlakuan konsentrasi $0 \%$ tepung ubi jalar ungu karena larutan sukrosa yang merupakan diskarida yang terdiri dari senyawa monosakarida Dglukosa dan D-fruktosa mempunyai sifat mudah larut dalam air, jika dipanaskan terus menerus hingga suhu $200^{\circ} \mathrm{C}$ akan menghasilkan warna karamelisasi(Goutara dan Wijandi, 1975).

\section{b. Tekstur}

Tekstur makanan merupakan komponen yang turut menentukan cita rasa makanan karena sensitifitas indera cita rasa dipengaruhi oleh konsistensi makanan. Makanan yang berkonsistensi padat atau kental akan memberikan rangsangan lebih lambat terhadap indera kita. Semakin kental suatu bahan, penerimaan terhadap intensitas rasa, bau, dan cita rasa semakin berkurang (Winarno, 2004).

Tabel 2 menunjukkan bahwa hasil ratarata nilai tekstur kue Yangko berturut-turut pada konsentrasi; $0 \%$ (nilai 2,44 ${ }^{\mathrm{f}}$ ), $15 \%$ (nilai $2,40^{\mathrm{f}}$ ), $30 \%$ (nilai $2,04^{\mathrm{f}}$ ), dan $50 \%$ (nilai $2,12^{\mathrm{f}}$ ) memiliki tekstur empuk yang tidak berbeda nyata. artinya tidak ada pengaruh nyata pada berbagai variasi konsentrasi tepung ubi jalar ungu terhadap tekstur kue Yangko yang dihasilkan.

Tekstur kue Yangko disebabkan oleh adanya kombinasi bahan pendukung berupa tepung ketan, tepung ubi jalar ungu, air dan gula pasir. Dalam proses pengadonan granula pati dalam ubi jalar ungu dan ketan akan menyerap air dan membengkak dan menyebabkan tekstur menjadi lunak. Kandungan amilosa dalam ubi jalar ungu juga berperan penting terhadap tingkat kekerasan tekstur, namun kandungan amilosa dalam ubi jalar ungu sampai pada konsentrasi $50 \%$ tepung ubi jalar ungumasih menghasilkan tekstur kue Yangko yang empuk dan tidak berbeda nyata dengan perlakuan tanpa penambahan tepung ubi jalar ungu dengan nilai tekstur $2,04^{\mathrm{f}}-2,44^{\mathrm{f}}$.

\section{c. Rasa}

Rasa merupakan bagian yang paling penting dari segi cita rasa suatu produk makanan yang dapat menimbulkan daya tarik bagi seseorang dan dapat menimbulkan suatu kesan dari produk olahan makanan. Tabel 2menunjukkan bahwa nilai tingkatan rasa rata- rata kue Yangko, paling tinggi pada konsentrasi $50 \%$ tepung ubi jalar ungu yaitu memilikirasa ubi jalar ungu dominan(nilai $4,28^{\mathrm{e}}$ ) dan berbeda nyata dengan perlakuan lainnya. Sedangkan nilai tingkatan rasa rata-rata terkecil kue Yangko terjadi pada konsentrasi $0 \%$ tepung ubi jalar ungudengan rasa gurih ketan (nilai1,16 ${ }^{\mathrm{c}}$ ) yang 
berbeda nyata dengan perlakuan lainnya. Namun perlakuan pada konsentrasi $30 \%$ tepung ubi jalar ungu(nilai3,16 ${ }^{\text {cd }}$ ) dan konsentrasi $15 \%$ tepung ubi jalar ungu (nilai2,92 ${ }^{\text {cd }}$ )menunjukkan cita rasa gurih ubi jalar ungu yang tidak berbeda nyata.

Rasa Yangko dipengaruhi oleh rasa manis dari gula pasir dan rasa gurih dari tepung ketan sangraidan rasaubi jalar ungu sangrai. Pada Tabel 2menunjukkan bahwa perlakuan pada konsentrasi 30\%tepung ubi jalar ungu(nilai $3,16^{\text {cd }}$ ) belum mampu meningkatkan rasa manis yang berasal dari ubi jalar ungu dan lebih dominan rasa ubi jalar ungu, karena ubi jalar yang digunakan masih segar,dan kadar gula dalam ubji jalar ungu masih rendah sehingga belum dapat menyebabkan rasamanis kue Yangko yang dihasilkan.

\section{d. Kesukaan}

Penilaian kesukaan keseluruhan merupakan penilaian terhadap semua parameter meliputi; warna, rasa, aroma dan tekstur. Penilaian keseluruhan meliputi warna yang menarik, rasa yang enak, aroma dan tekstur yang baik. Tabel 2 menunjukkan bahwa penambahan konsentrasi $30 \%$ tepung uji lajar ungu memberikan penilaian $1,72^{\mathrm{g}}-2,72^{\mathrm{g}}$ yang masih disukai oleh panelis dantidak berbeda nyata. Sedangkan substitusi pada konsentrasi $50 \%$ tepung ubi jalar ungu dengan nilai kesukaan $3,92^{\mathrm{h}}$ menghasilkan kue Yangko ubi jalar ungu yang tidak disukai danberbeda nyata perlakuan lainnya.

Semakin tinggi konsentrasi ubi jalar ungu dalam kue Yangko, maka tingkat kesukaan keseluruhan kue Yangko cenderung mengarah ketingkat yang tidak disukai, karena rasa ubi jalar ungu semakin dominan. Perlakuan substitusi pada konsentrasi 30\%tepung ubi jalar ungu,tingat kesukaan masih dapat diterima oleh panelisyang tidak berbeda nyata dengan tingkat kesukaan pada konsentrasi 15 $\%$ tepung ubi jalar ungu dan konsentrasi $0 \%$ tepung ubi jalar ungu. Dengan demikianpembuatan kue Yango ubi jalar ungu pada konsentrasi $30 \%$ tepung ubi jalar unguditetapkan sebagai perlakuan terpilih dan memiliki sifat organoleptik; rasa ubi jalar ungu, warna ungu tua, tekstur yang empuk, dan masih disukai.

\section{Uji Kimia Yangko Ubi Jalar Ungu Pada Berbagai Konsentrasi Ubi Jalar Ungu}

Analisis data menggunakan uji sidik ragam atau analysis of variance (anova) pada derajat signifikan $(\alpha)=0,05$, jika p hitung $\leq p$ 0,05 artinyaada pengaruh nyata uji kimia kue Yangko dari tepung ubi jalar ungu. Hasil uji mutu terhadap kadar air, kadar serat pangan dan aktivitas antioksidan seperti pada Tabel 3 .

Tabel 3. Hasil Uji Kimia Kue YangkoPada Berbagai Konsentrasi Tepung Ubi Jalar Ungu.

\begin{tabular}{|c|c|c|c|}
\hline \multirow{4}{*}{$\begin{array}{l}\text { Konsentrsi } \\
\text { tepung ubi } \\
\text { jalar ungu }\end{array}$} & \multicolumn{3}{|c|}{ Hasil analisis kimia } \\
\hline & Kadar & Kadar & Aktivitas \\
\hline & Air & Serat & Antioksidan \\
\hline & $(\%)$ & $(\% \mathrm{db})$ & $(\% \mathrm{db})$ \\
\hline $0 \%$ & $36,22^{c}$ & $11,77^{\mathrm{n}}$ & $11,91^{\mathrm{h}}$ \\
\hline $15 \%$ & $41,82^{b}$ & $15,02^{\mathrm{m}}$ & $27,33^{\mathrm{g}}$ \\
\hline $30 \%$ & $43,07^{\mathrm{a}}$ & $17,38^{1}$ & $93,53^{f}$ \\
\hline $50 \%$ & $43,21^{\mathrm{a}}$ & $19,18^{k}$ & $130,26^{\mathrm{e}}$ \\
\hline
\end{tabular}

Keterangan :

Nilai yang mempunyai notasi sama pada kolom yang sama menunjukkan tidak ada beda nyata antar perlakuan konsentrasi tepung ubi jalar ungu.

\section{Kadar Air}

Air merupakan komponen penting dalam bahan pangan karena air mempengaruhi tektur, cita rasa, dan perubahan reaksi enzimatis maupun pertumbuhan mikrooranisme dalam makanan. Hasil analisis sidik ragam kadar air pada Tabel 3 menunjukkan bahwa semakin tinggi konsentrasi tepung ubi jalar ungu, memberikan pengaruh yang nyata terhadap peningkatan kadar air dalam kue Yangko dengan kisaran kadar air 36,22 $\%-43,21^{\mathrm{a}} \%$. Kadar air terendah sebesar $36,22^{\mathrm{c}} \%$ pada perlakuan konsentrasi $0 \%$ tepung ubi jalar ungu dan tertinggi pada konsentrasi $50 \%$ tepung ubi jalar ungu sebesar 43,21 ${ }^{\mathrm{a}} \%$. Meningkatnya kadar air ini karena adanya kandungan serat dalam tepung ubi jalar ungu yang sebagian besar mengandung sellulosa, zat pektin dan lignin yang mudah mengikat air. Serat merupakan molekul berbentuk polimer 
dengan ukuran besar, strukturnya kompleks dan banyak mengandung gugus hidroksil, yang mempunyai kapasitas yang besar mengikat air.

Gugus hidroksil bebas bersifat polar danmempunyai struktur matriks yang berlipatlipat yang dapat memberi peluang bagi terjadinya pengikatan air melalui ikatan hidrogen. Penambahan air pada pembuatan adonan kue Yangko akan menyebabkan air terserap dan terikat kedalam serat pangan secara cepat dan tidak terlepas selama proses pencetakan. Semakin tinggi konsentrasi tepung ubi jalar ungu, menyebabkan kandungan air akan semakin meningkat sejalan dengan semakin banyaknya jumlah serat dalam kue Yangko. Kue Yangko yang memiliki kadar air $36.22 \%-43,21 \%$ tergolong jenis makanan yang berkadar air dan air bebas yang sedang sehingga menyebabkan mudah berlangsungnya reaksi biokimia dan mikrobiologis yang menyebabkan perubahan sifat fisis dan sifat kimia.

\section{Kadar Serat}

Serat pangan merupakan karbohidrat yang tidak dapat dicerna oleh enzim- enzim pada pencernaan manusia dan akhirnya sampai di usus besar. Serat alami oligosakarida yang tersimpan dalam ubi jalar ungu menjadi komoditas bernilai dalam pengkayaan produk pangan olahan. Serat makanan secara umum merupakan polisakarida yang terdapat pada dinding sel tanaman, beberapa dari senyawa tersebut bukan merupakan polisakarida maupun senyawa-senyawa seperti pektin interseluler, lignin yang merupakan senyawa non-karbohidrat sturktural dan beberapa polisakarida interseluler seperti gum dan musilase.

Hasil uji sidik ragam pada Tabel 3 menunjukkan bahwa semakin tinggi konsentrasi tepung ubi jalar ungu dalam kue Yangko, kadar serat pangan semakin tinggi dan berbeda nyata pada setiap perlakuan. Kadar serat pangan terendah sebesar $11,77^{\mathrm{n}} \%$ (db) pada perlakuan tanpa penambahan tepung ubi jalar ungu dan konsentrasi tertinggi pada perlakuan konsentrasi $50 \%$ tepung ubi jalar ungu sebesar $19,18^{\mathrm{k}} \%$. (db). Meningkatnya kandungan serat pangan dalam kue Yangko ubi jalar ungu ini berasal dari tepung ubi jalar ungu yang ditambahkan sebagai bahan pengganti tepung ketan. Serat pangan dan serat alami oligosakarida yang tersimpan dalam ubi jalar ungu adalah komoditas yang bernilai untuk produk pangan olahan dan ubi jalar ungu segar memiliki kandungan serta pangan sebesar 3,7 \% (Anonim,2008; Ginting dkk., 2011).

\section{Aktivitas Antioksidan}

Antioksidan merupakanmolekul yang mampu memperlambat atau mencegah proses oksidasi molekul lainyang dapat menghasilkan radikal bebas, sehingga antioksidan dapat mencegah reaksi berantai berikutnya. Warna ungu pada ubi jalar disebabkan oleh adanya zat warna alami yang disebut antosianin dan senyawa antosianin berfungsi sebagai antioksidan dan penangkap radikal bebas, karena antosianin merupakan senyawa poli fenol yang efektif menangkap radikal bebas. Aktivitas antioksidan diukur dengan berbagai cara, antara lain dengan pengujian DPPH. Prinsip pengujian dengan metode DPPH ini adalah reaksi antara radikal bebas DPPH dengan hidrogen. Ekstrak antioksidan merupakan donor hidrogen dan akan menangkap radikal DPPH

Hasil uji sidik ragam pada Tabel 3 menunjukkan bawa semakin tinggi konsentrasi tepung ubi jalar ungu pada kue Yangko menyebabkan semakin meningkatnya aktivitas antioksidan dan berbeda yang nyata. Aktivitas antioksidan paling rendah sebesar $11,91^{\mathrm{h}} \%(\mathrm{db})$ terdapat pada perlakuan konsentrasi $0 \%$ tepung ubi jalar ungu, sedangkan aktivitas tertinggi terdapat pada konsentrasi $50 \%$ tepung ubi jalar ungu sebesar 130,26 \% (db).

Meningkatkan aktivitas antioksidan dalam kue Yangko karena jumlah tepung ubi jalar ungu pada kue Yangko semakin banyak, warna ungu semakin pekat, dan aktivitas antioksidannya makin tinggi.Hal ini karena ubi jalar ungu segar memiliki aktivitas antioksidan yang tinggi sekitar 
61,07\%(Retnati, 2009) dan juga memiliki kandungan vitamin $\mathrm{C}$ yang cukup tinggi yang juga berfungsi sebagai antioksidan (Ginting, dkk., 2011). Total kandungan antosianin ubi jalar ungu bervariasi pada setiap tanaman, yaitu berkisar antara $20 \mathrm{mg} / 100 \mathrm{~g}$ sampai 600 $\mathrm{mg} / 100 \mathrm{~g}$ berat basah. Total kandungan antosianin ubi jalar ungu adalah $519 \mathrm{mg} / 100 \mathrm{~g}$ berat basah (Shinta Ferlina,2009).Keberadaan senyawa antosianin pada ubi jalar ungu yaitu pigmen yang terdapat pada ubi jalar ungu atau merah dapat berfungsi sebagai komponen pangan sehat. Zat antioksidansangat berguna untuk melawan radikal bebas yang berasal dari zat-zat racun.

\section{Uji Organoleptik terhadap Umur Simpan Kue Yangko Ubi Jalar Ungu.}

Kue Yangko pada kondisi terpilih pada konsentrasi $30 \%$ tepung ubi jalar ungu selanjutkan dikemas dalam plastik tertutup dan disimpan pada suhu ruang selama 7(tujuh) hari dan hasil uji organoleptik seperti pada Tabel 4.

Tabel 4. Hasil uji organoleptik kue Yangko konsentrasi $30 \%$ tepung ubijalar ungu pada berbagai waktu simpan pada suhu ruang yang dikemas dalam kantong plastik

\begin{tabular}{|c|c|c|c|c|}
\hline \multirow{2}{*}{ Jenis uji } & \multicolumn{3}{|c|}{ Nilai Umur Simpan } & \multirow{2}{*}{$\begin{array}{c}\text { Keterangan } \\
\text { skor/nilai }\end{array}$} \\
\hline & $\begin{array}{c}1 \\
\text { hari }\end{array}$ & 4 hari & $\begin{array}{c}7 \\
\text { hari } \\
*)\end{array}$ & \\
\hline a. Warna & $\underset{\substack{a \\
\mathrm{a}}}{3,60}$ & $3,92^{\mathrm{a}}$ & - & $\begin{array}{l}1=\text { Putih }- \\
\text { krem } \\
2=\quad \text { sedikit } \\
\text { ungu } \\
3=\quad \text { Ungu } \\
\text { muda } \\
4=\text { Ungu tua } \\
5=\quad \text { Sangat } \\
\text { Ungu }\end{array}$ \\
\hline b. Rasa & $\begin{array}{l}2,96 \\
\mathrm{c}\end{array}$ & $3,36^{c}$ & - & $\begin{array}{l}1=\text { Gurih } \\
\text { beras ketan } \\
\text { dominan } \\
2=\text { Agak } \\
\text { gurih beras } \\
\text { ketan } \\
3=\text { Ubi jalar } \\
\text { ungu } \\
4= \\
\text { ungu Ubi } \\
\text { dominan } \\
5=\quad \text { Langu }\end{array}$ \\
\hline
\end{tabular}

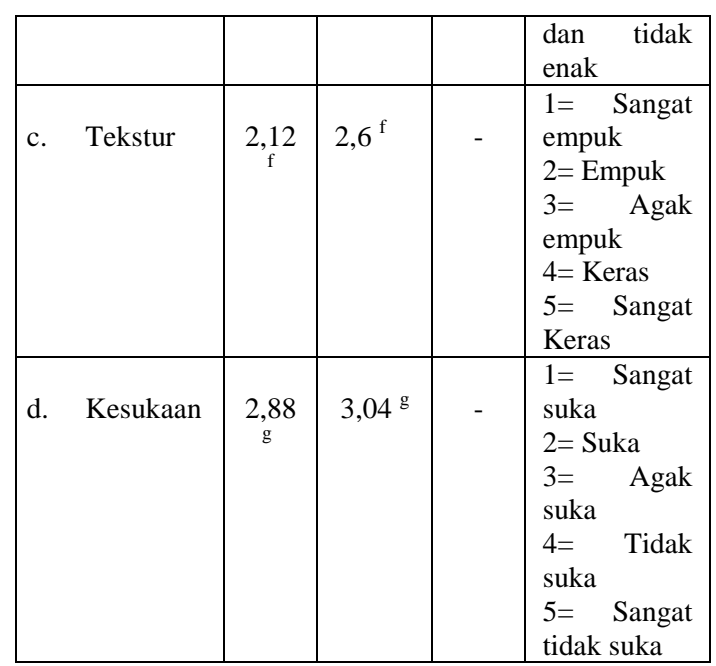

Keterangan : skor yang mempunyai notasi sama pada baris yang sama menunjukkan tidak ada beda nyata antar perlakuan waktu simpan.

*) waktu simpan hari ke-7 tidak dilakukan uji sensoris karena dipermukaan kue Yangko sudahditumbuhi jamur dan tidak layak dikonsumsi.

Tabel 4 menunjukkan bahwa penyimpanan pada hari ke-7 dipermukaan kue Yangko terlihat secara fisis telah terjadi pertumbuhan miselia jamur yang merata berwarna putih dan sepora-spora yang berwarna kuning, warna hijau dan warna hitam sehingga tidak layak dikonsumsi. Hasil analisis sidik ragam terhadap warna kue Yangko pada pada Tabel 4yang disimpan selama 4 hari berwarna ungu tua (nilai $3,60^{\mathrm{a}}-3,92^{\mathrm{a}}$ ) dan tidak berbeda nyata dengan warna ungu tua pada penyimpanan hari ke-1. Hal ini karena penyimpanan selama 4 hari belum terjadi degradasi senyawa antosianin yang signifikan pada kue Yangko.

Hasil analisis sidik ragam terhadap rasa ubi jalar ungu pada kue Yangko pada Tabel 4 selama penyimpanan 4 (empat) hari menunjukkan bahwa rasa ubi jalar ungu (nilai $2,96^{\mathrm{c}}-3,36^{\mathrm{c}}$ ) dan tidak berbeda nyata.Hal ini menunjukkan bahwa peyimpanan selama 4 hari pada suhu ruang secara fisik belum terjadi degradasi senyawa karbohidrat, protein dan senyawa lainnya yang signifikan yang dapat menghasilkan senyawa baru yang menimbulkan rasa yang tidak enak pada kue Yangko ubi jalar ungu.

Hasil analisis sidik ragam terhadap tekstur kue Yangko pada Tabel 4 selama penyimpanan 
1 hari dan 4 hari memiliki nilai tekstur $2,12^{\mathrm{f}}-$ $2,60^{\mathrm{f}}$ yaitu agak empukdankeduanya tidak berbeda nyata, hal ini karena daya ikat molekul air, ikatan ion dan ikatan kovalen komponen amilum, protein, serat dan senyawa lainnya pada kue Yangko masih stabil. Hasil analisis sidik ragam terhadap tingkat kesukaan kue Yangko pada Tabel 4 selama penyimpanan hingga 4 hari masih disukai oleh panelis dengan nilai $3,04^{\mathrm{g}}$ agak suka dan tidak berbeda nyata dengan waktu simpan 1 hari dengan nilai $2,88^{\mathrm{g}}$.

\section{KESIMPULAN}

Variasi konsentrasi tepung ubi jalar ungu dalam kue Yangko mempengaruhi kadar air, kadar serat pangan, aktivitas antioksidan, warna, rasa dan tingkat kesukaan kue Yangko ubi jalar ungu. Substitusi konsentrasi $30 \%$ tepung ubi jalar ungu dapat menghasilkan kue Yangko ubi jalar ungu yang masih diterima dan disukai oleh panelis dan memiliki sifat sensoris: warna ungu tua (nilai 3,64 ), rasa ubi jalar ungu (nilai 3,16) dan tekstur empuk (nilai 2,04), kadar air 43,07\%, kadar serat pangan $17,38 \%(\mathrm{db})$, aktivitas antioksidan $93,53 \%(\mathrm{db})$ dan memiliki umur simpan selama 4 hari.

\section{DAFTAR PUSTAKA}

Anonim. 2008. Khasiat Ubi Jalar. http://biensnaturels.blogspot.com/ 2009/09/khasiatubi-jalar.html (Diakses tanggal 05 Januari2010.

Bambang Kartika, Pudji Hastuti dan Wahyu Supartono. 1988. Pedoman Uji Inderawi Bahan Pangan. PAU Pangan Gizi UGM. Yogyakarta.

Gaotara dan S Wijandi, 1975, Dasar Pengolahan Gula Jilid I, Departemen THP Fatemeta IPB, Bogor.

Ginting, E., Utomo, J.S., Yulifianti, R., dan Yusuf, M. 2011. Potensi Ubi Jalar Ungu Sebagai Pangan Fungsional. Journal Iptek Tanaman Pangan. Vol.6 No.1.
Harsojuwono, B.A., Arnata,I.W., dan Puspawati, G.A.K.D. 2011. Rancangan Percobaan Teori, Applikasi SPSS dan Excel. Lintas Kata Pulishing.

Husnah, S. 2010. Pembuatan Tepung Ubi Jalar Ungu (Ipomea batatas Var. Ayamurasaki) dan Aplikasinya Dalam Pembuatan Roti Tawa. Fakultas Teknologi Pertanian Institut Pertanian Bogor. Bogor.

Jawi I M, Suprapta D N, Sutirtayasa I WP. 2007. Efek Antioksidan Ekstrak Umbi Ubi Jalar Ungu (Ipomoiea Batatas L) Terhadap Hati Setelah Aktifitas Fisik Maksimal dengan Melihat Kadar AST dan ALT Darah pada Mencit. Dexa Media.; 20 (3)

Jiao, Y., Jiang., Zhai, W., dan Yang, Z. 2012. Studies On Antioxidant Capacity of Anthoyanin Extract From Purple Sweet Potato (Ipomea batatas L.). African Journal Of Biotechnology. Vol. 11 (27), pp. 7046-7054.

Retnati. 2009. Pengaruh Penambahan Ekstrak Berbagai Jenis Ubi Jalar (Ipomoea batatas L.) terhadap Jumlah Bakteri Asam Laktat dan Aktivitas Antioksidan Yoghurt. Skripsi S-1. Fakultas Pertanian Universitas Sebelas Maret Surakarta.Surakarta

Singh, S., C.S. Riar, dan D.C. Saxena. 2008. Effect of Incoporating Sweetpotato Flour to Wheat Flour on The Quality Characteristics of Cookies. African Journal of Food Science.; 2(6): 65-72. )

Shinta Ferlina. 2009. Khasiat Ubi Jalar Ungu. http://www.khasiatku.com/ubijalar-ungu/ (diakses tanggal 29 Juli2009). 
Sudarmadji, S., Haryono, B., dan Suhardi. 2010. Prosedur Analisa Untuk Makanan dan Pertanian. Liberty. Yogyakarta.

Winarno, F.G. (2004). Kimia Pangan dan Gizi. PT. Gramedia Pustaka Utama, Jakarta.

Yusuf, M., Rahayuningsih, St.A. dan Pambudi, S. 2003. Pembentukan Varietas Unggul Ubi Jalar Produksi Tinggi yang Memiliki Nilai Gizi dan Komersial Tinggi. Laporan Teknis. Balitkabi. 